DOI: 10.24234/wisdom.v14i1.325

Natalia BIGUNOVA,

Ganna OLIINYK,

Olena SELIVANOVA

\title{
COMMUNICATION NOISE AS A DISCOURSE COMPONENT
}

\begin{abstract}
The paper focuses on the investigation of communicative noise at various levels of monocultural and intercultural communication. Communication noise is seen as a component of a communicative event, functioning as obstacles of different nature that lower the effectiveness of communication, destabilize it and are able to cause communicative conflict or the breakdown of communication. In linguistic pragmatics, the main features of communication noise have been identified as vagueness and ambiguity of a message: vagueness is characterized by a more significant degree of noise than ambiguity. The authors of the article have tried to probe more deeply into the area of communication noise by singling out levels of the communicative situation. The article offers a differentiation of five discourse levels: verbal-semiotic, cognitive-interpretational, interactive, ontological and sociocultural levels. The central part of the paper analyzes the barriers that cause communication noise at each of the offered levels of the communicative situation. The raised issues offer prospects for further research, such as investigating of noise effects in real communication, identifying a set of causes leading to communication noise, as well as noise-resistant factors, preventing or removing it.
\end{abstract}

Keywords: communication, discourse, communication noise, barrier, vagueness, ambiguity.

Introduction

Modern communicative linguistics and discourse analysis have recently registered decisive attempts to penetrate into the component structure of a communicative event (Eco, 1998; Leech, 1981; Lakoff, 1987; Frumkina, 2003; Makarov, 2003; Selivanova, 2010; Bigunova, 2019, et al.). Communication noise is seen as one of such components, defined as obstacles of different nature that lower the effectiveness of communication, destabilize it and are able to cause communicative conflict or the breakdown of communication. Ancient Greeks used the word atopon (deprived of place) to define obstacles as utterances which cause surprise and do not meet the communicants' expectations.

In the philosophy of language, the issues of misunderstanding and communicative failure have long received a fair amount of attention. The first philosophers to raise those issues were Jain philosophers, ancient Indian religious thinkers, who as long ago as in IX-VI centuries B.C. differentiated among 100 karmas and organized them into two broad groups: those impeding cognition and those impeding understanding. Moreover, misunderstanding is known to be the primary basis for Jainism. 
In the Middle Ages, T. Hobbes defined understanding is a sort of imagination. Understanding is, T. Hobbes (1994) says, "the imagination that is raised in man (or any other creature endued with the faculty of imagining) by words or other voluntary signs" (p. 45). According to T. Hobbes, humans have a sort of understanding that other creatures lack. They can also understand the "conceptions and thoughts" (Hobbes, 1994, p. 45) of others from their uses of language.

Understanding is for T. Hobbes, the work of the faculty of imagination, and crucially involves language. An account of the workings of language is thus crucial for his having an account of the workings of the mind. ${ }^{1}$

G. W. Leibniz (1989), a prominent German philosopher, says, "The senses, although they are necessary for all our actual knowledge, are not sufficient to give us the whole of it, since the senses never give anything but instances, that is to say, particular or individual truths. Now all the instances which confirm a general truth, however numerous they may be, are not sufficient to establish the universal necessity of this same truth, for it does not follow that what happened before will happen in the same way again. ...From which it appears that necessary truths, such as we find in pure mathematics, and particularly in arithmetic and geometry, must have principles whose proof does not depend on instances, nor consequently on the testimony of the senses, although without the senses it would never have occurred to us to think of them..." (p. 52).

In the $20^{\text {th }}$ century, the workout of the first models of information output was followed by the definition of the components of communication noise developed by the American mathema-

\footnotetext{
1 See: Thomas Hobbes (Stanford Encyclopedia of Phi-
} losophy). https://plato.stanford.edu/entries/hobbes/. ticians C. E. Shannon and W. Weaver in 1949 when they offered transmission model, which is still considered the most well-known and influential formal model of. The aim of C. E. Shannon was the signal transmission from source to destination through transmitter and receiver across the channel with minimal interference or error. The information theory was initially developed to separate noise from the signals carrying the information. W. Weaver extended and applied Shannon's information theory for different kinds of communication (Shannon \& Weaver, 1949).

W. Weaver reported that noise could be produced within the transmission and reception system, which has a physical nature or can be semantic, which can be the result of mismatching encoder and decoder or human interpretation. As W. Weaver found out, relative to the broad subject of communication, there might occur problems at three levels (technical, semantic, and efficacious). The technical problems are concerned with the accuracy of transference from the sender to the receiver of sets of symbols (written speech), or of a continuously varying signal (telephonic or radio transmission of voice or music), or of a continuously varying two-dimensional pattern (television), etc. ${ }^{2}$ The semantic problems are concerned with the interpretation of meaning by the receiver, as compared with the intended meaning of the sender. The effectiveness problems are concerned with the success with which the meaning conveyed to the receiver leads to the desired conduct on his part (Shannon \& Weaver, 1949). ${ }^{3}$

2 See: Recent Contributions to The Mathematical Theory of... http://ada.evergreen.edu/ arunc/texts/ cybernetics/weaver.pdf.

3 See: EDRS PRICE DESCRIPTORS Syntax IDENTIFIERS ABSTRACT The... https://files.eric.ed.gov/fulltext/ED079767.pdf. 
In W. Weaver and C. E. Shannon's model, the components of communication noise and the noise source determined the presence of two signals, which served a primary finding for one of the significant axioms of the theory of verbal communication, highlighting the absence of isomorphism between the transmitted information and meaning, perceived and interpreted by the addressee (Shannon \& Weaver, 1949). In the further attempts on modelling the process of information transmission, the noise component was referred not to the transmission channel but to the signal itself (Eco, 1998, pp. 36-38), code (Yakobson, 1975), or all the constituents and operations of the communicative situation in modern information models.

The problem of communication noise in the theory of verbal communication was rediscovered when the problems of message effectiveness were touched upon. The psycholinguistic approach offered an insight into communication noise within the problem of speech perception, determined by the recipient's strategy to choose an optimal and effective way of perception judging by the correlation of signal and noise (Leontev, 1999, p. 132). There have been identified immunity factors which determine speech perception when the level of noise is increased: frequency of word usage, as the works of I. Goldiamond \& W. F. Hawkins (1958), R. Frumkina (1995), D. Rothwell (2004) report, the significance of the transmitted information, as the works of A. A. Uhtomskiy (1950), A. A. Leontev (1999), R. C. Martin \& M. L. Freedman (2001) report, cognitive operations of comprehending an interlocutor's message information content, as the works of C. Fillmore (1982), A. O. Oliinyk (2019) report.

U. Eco suggests that an everlasting tension within the process of communication indicates the existence of double oppositional tendency. On the one hand, there exists a drive towards a homologation which works in the direction of simplification of communication in the sense that it renders the transfer of information null or it impoverishes the dialogical exchange. On the other hand, an opposite tendency encourages difference which itself improves that value of communication as such at the expenses of an increase of a degree of mutual untranslatability that inevitably renders the communication more arduous (Eco, 1989, p. 58).

\section{$\mathrm{U}$. Eco defines aberrant decoding as a "be-} trayal of the sender's intentions" and mentions the possibility that the addressee's codes and subcodes and context produce an interpretation unforeseen by the sender. In such cases, when the addressee cannot isolate the sender's codes or successfully substitute his own codes or subcodes for them, the message becomes pure noise. $^{4}$

According to U. Eco, it is at the level of subcodes and actual circumstances that the content of messages can be changed. If we want to lower the risk of making a mistake caused by noise, we should complicate the code, i.e. insert redundancy elements which exclude entropy (disorder) and transform disorder into the system of preestablished probabilities (Eco, 1989). Thus, the more considerable the amount of information, the more complicated its communication; the clearer the message, the smaller the amount of information. For this reason, C. E. Shannon and $\mathrm{W}$. Weaver consider information as directly proportional to entropy.

In linguistic pragmatics, the main features of communication noise have been identified as

4 See: Umberto Eco's Model of Communication - Semiotics. https://semioticon.com/sio/courses/communication-and-cultural-studies/umberto-ecos-model-ofcommunication/. 
vagueness and ambiguity of a message: vagueness is characterized by a more significant degree of noise than ambiguity, though both features can cause noise or breakdown of communication (Leech, 1981, p. 12). According to G. Leech, vagueness can be eliminated by additional information related to the vague state of things, while ambiguity reflects two variants of interpretation and can be translated onto an intentional strategic programme of communicative interaction. Ambiguity can be eliminated utilizing further progress of interaction: it does not need demand any input of additional information (Leech, 1981, p. 12). As U. Eco (1998) remarks, an utterly ambiguous message is informative, but it trenches on noise (p. 79). The cognitive nature of vagueness is caused by the absence or incompleteness of interpretive frame (C. Fillmore's term), situation model or microstructure (T. van Dijk's term) in the recipient's mind which determine the understanding of a message. Ambiguity is based on the presence of two cognitive structures in the addressee's mind, the choice between which is made when the reader moves forward in a text or discourse.

As A. O. Oliinyk reports, a recipient is unable to grasp the meaning of the message for several reasons. Apart from the ambiguity of the meaning of the message, the speaker might be deceitful or dishonest, or his/her speech might be indistinct. Furthermore, the addressee himself/herself might be at fault if he/she is unable to make effective interpretative operations and thus gets incomplete mental representation of a communicative message. Thus, poor communicative skills, poor thesaurus, lack of background knowledge lead to communicative failure and misunderstanding (Oliinyk, 2019).

We have tried to probe more deeply into the area of communication noise by singling out lev- els of the communicative situation. Following I. Susov's conception, discourse stratification implies three levels: formal-semiotic, cognitive-interpretational and social-interactive (Susov, 1988, pp. 7-13). The first one corresponds to the verbal-sign form of message or text; the second one corresponds to the content of the message that is interpreted by the addressee; the third one is linked to the interaction in a particular social environment that involves a set of intentions, strategies and responses of the communicants. We believe this stratification is grounded on the conception of unilateralism of a language sign, since the semiotic level is limited by a form only, and the information bulk located within this form produced by the addresser and interpreted by the addressee belongs to the second level. This conception is similar to Y. V. Tarasova's (2000) stratification of discourse, which includes cognitive, social-cultural and interpersonal levels of speech activity (p. 276). This classification lacks the sign level of speech, and the correlation of cognitive and interpersonal levels remains obscure, as any interaction is based on communicative competence, which has cognitive nature.

We offer differentiation of five discourse levels:

- verbal-semiotic level, manifested by sign potential of verbal and paraverbal means in a text or a message;

- cognitive-interpretational level, involving two content bulks of communication: the one produced by the addresser and the one perceived by the addressee;

- interactive level, involving the interaction of communicants, proceeding from their motives, intentions, strategical programmes and interpretations, as well as situational roles;

- ontological level, determined by the 
communicative situation (place, time, their possible discreteness, conditions and circumstances of communication);

- sociocultural level, maintaining communicative interaction through social and cultural parameters (status and positional roles of communicants, the context of culture and social sphere, their norms and conventions). These levels are synergistically integrated and can not be separated, and they guarantee the interaction of all discourse components. Communication noise can occur at any of the levels.

At the verbal-semiotic level communication noise is manifested by the certain phonetic-prosodic organization of a message (speech impediment, speech difficulties, low voice, hesitations, wrong or non-motivated logical stress), incongruence as a discrepancy of verbal and paraverbal means, etc. It is considered that communication noise can also be caused by speech faults, however, it is worth mentioning that not all speech faults lead to communication noise: if the addressee is capable of semantic-syntactic and situational prognostication, the noise is minimized, since man's perception possesses a mechanism that can, on the one hand, segment the perceived speech and, on the other hand, can correct faults ("Speech Methods and Mistakes", 1989, pp. 50-55). Noise effects produced by inevitable speech mistakes are easily eliminated by the context and the addressee's knowledge.

At this discourse-level barriers are also caused by incWODEreased use of metaphors which creates excessive connotational colouring. In literary discourse, for instance, excessive use of metaphors is a characterizing feature of P. Yakobson 's prose. Describing events, as well as the protagonist's not entirely convincing reflections and considerations, P. G. Wodehouse resorts to abounding use of metaphors, which creates the ironical effect, e.g.:

"In a matter of seconds by Shrewsbury clock, as Aunt Dahlia would have said, I could see that she was going to come out with one of those schemes or plans of hers that not only stagger humanity and turn the moon to blood but lead to some unfortunate male - who on the present occasion would, I strongly suspected, be me - getting immersed in what Shakespeare calls a sea of troubles if it was Shakespeare" (Wodehouse, 2009, p. 35).

Excessive use of metaphors and associativity occur as a result of adding certain lexicodes to the established code systems. Lexicodes are semantic codes for the codes (Eco, 1998, p. 72). In literary criticism, such a noise is defined as the effect of "alienation" used in theatre practice by B. Brecht or "defamiliarization" (also translated as "estrangement") introduced into metalanguage by the representatives of Russian formalism (Shklovsky, 1990). This effect is based on deautomatization of perception and understanding of familiar notions not within usual associations but as new things, never encountered before, and thus decoded with difficulty (Shklovsky, 1990, p. 6). This resulted in the conception of "abstruse language" as a language for impeded perception, e.g.:

"It was several weeks before Irie understood that weathermen were the secular antithesis of Hortense's life work, which was, essentially, a kind of super cosmic attempt to second-guess the Lord with one almighty biblical exegesis of a weather report" (Smith, 2001, p. 177).

At this level communication noise also occurs if a participant or participants do not understand the meaning of words: their attempts to interpret the vague meaning result in changing 
the topic or in a comedic effect in dialogic speech reproduced in a fictional text. To illustrate the latter point here is an extract from M. Twain's novel in which Tom Sawyer and his friends are about to rob carriages on the road and keep them till they are ransomed. The trouble is that the boys do not know the word ransom and try to guess its meaning:

"Stuff! stealing cattle and such things ain't robbery; it's burglary," says Tom Sawyer. "We ain't burglars. That ain't no sort of style. We are highwaymen. We stop stages and carriages on the road, with masks on, and kill the people and take their watches and money."

"Must we always kill the people?"

"Oh, certainly. It's best. Some authorities think different, but mostly it's considered best to kill them - except some that you bring to the cave here, and keep them till they're ransomed."

\section{"Ransomed? What's that?"}

“I don't know. But that's what they do. I've seen it in books; and so of course that's what we've got to do."

"But how can we do it if we don't know what it is?"

"Why, blame it all, we've got to do it. Don't I tell you it's in the books? Do you want to go to doing different from what's in the books, and get things all muddled up?"

"Oh, that's all very fine to say, Tom Sawyer, but how in the nation are these fellows going to be ransomed if we don't know how to do it to them? - that's the thing I want to get at. Now, what do you reckon it is?"

"Well, I don't know. But per'aps if we keep them till they're ransomed, it means that we keep them till they're dead."

"Now, that's something like. That'll an swer. Why couldn't you said that before? We'll keep them till they're ransomed to death; and a bothersome lot they'll be, too - eating up everything, and always trying to get loose" (Twain, 2012, p. 95).

At the verbal-semiotic level communication noise is also caused by:

- redundant economy and excessiveness of speech devices:

At last the detective came back on the line. "There's a smell about the man, but he's never been charged with anything."

"What do you mean, 'a smell'?"

"Well, he wanted to buy a hotel out Aberfoyle way, but the owner didn't want to sell. Then things started happening” (Beaton, 2001, p. 80).

- the lack of antecedent of pronoun metaphor or the lack of latent antecedent, which is present only in the addresser's mind, but not of which the addressee is unaware:

"She sat down on the edge of the bed and Pruney sat next to her, twisting a handkerchief in her nervous fingers.

"What is it?" asked Priscilla gently.

"He loved me."

"Who?”

"Captain Bartlett. He loved me," said Pruney, striking her bosom" (Beaton, 1987, p. 88).

- abundant number of mentioned people without any specifications and chaotic speech structure:

"They asked me if I had any family. I said I did. They asked me who my family was. I said it was Father, but Mother was dead. And I said it was also Uncle Terry, but he was in Sunderland and he was Father's brother, and it was my grandparents, too, but three 
of them were dead and Grandma Bur-

ton was in a home because she had senile dementia and thought that I was someone on television" (Haddon, 2012, p. 11).

- violation of the distribution of language units and grammatical coherence, the fragmentary character of speech:

"Martha never told me we had a guest.

Forgive me if I appeared inhospita-

ble... I--er... Oh, why doesn't somebody

else say something” (Waugh, 2012, p.

45).

- ellipsis, compensated by further clarifying of matters:

"She said she was sorry for me and brought me cakes and scones. But I knew what she wass after."

"That being?" prompted Hamish.

She nodded her head towards a Welsh dresser. "That."

"The dresser?"

"That platter wi' the three women and the man on it" (Beaton, 2011, p. 77).

At the second (cognitive-interpretational) discourse level communication noise can be caused by the lack of common for the speaker and the addressee thesaurus fragments, background and encyclopedia knowledge, which greatly impedes communication. At this level communication noise is caused by:

- alogisms as lack of logic or some special logic, not clear to other people:

"In the present instance, there is absolutely nothing to say 'Sir?' about. The plan I have put forward is entirely reasonable and icily logical, and should excite no sirring whatsoever. Or don't you think so?"

“Well, sir-” (Wodehouse, 2015, p. 77).

- hints:

"When she had finished, John ordered brandies and then leaned across the table and gazed into her eyes".

"What about it, Agatha?"

Agatha looked at him, puzzled.

"What about what?"

"You and me making a night of it" (Beaton, 2009, p. 108).

- speech paradox, based on the effect of expectation, resolved further in the text:

"They haff arrested the husband."

"Paul Thomas? Why?"

“No' him. Her first husband."

"Her-?"

“Aye, it turns out that lodger o' theirs, John Parker, used tae be married to her" (Beaton, 2011, p. 59).

- mismatching of the interlocutors' knowledge:

"You must know something!' says Jemima. 'You slept with him, for goodness sake! He must have some secret. Some weak point.' 'An Achilles' heel,' puts in Lissy, and Jemima gives her an odd look. 'It doesn't have to be to do with his feet,' she says, and turns to me, pulling a 'Lissy's lost it' face" (Kinsella, 2003, p. 298).

- difficulties of decoding the implication:

'Sorry,' she said again, 'but I don't want to think about wills. I don't want to think about money and stuff. It just seems - kind of grotesque."

“Grotesque?”'Tamsin said.

Amy picked the banana skin off the radiator and dropped it on the table.

She said, 'Doesn't matter-'

'It does matter,' Chrissie said. 'What do you mean, that hearing what's in the will is grotesque?"

"Well,' Amy said, shuffling, 'sort of wrong, then."

'Wrong?' Tamsin said, with the same emphasis.

'Yes,' Amy said, 'because it isn't just 
us. Is it?"' (Trollope, 2010, p. 32).

- lack of interrelationship of the situations that each of the communicants perceives in their own way:

"But you were going to tell me why you came here. Just for a chat about old times, was it?"

"It's with ref to that book you pinched from the Junior Ganymede".

"I wish you wouldn't use that word "pinch",' he said, looking puff-faced. It was plain that I had given offence. 'I simply borrowed it because I needed it in my business. They'll get it back all right" (Wodehouse, 2004, p. 56).

- ciphered text which the addressee cannot decipher because he does not possess the key, as can be observed in C. Doyle's story "The "Gloria Scott" (the note, which can be deciphered if one read only every third word):

"The supply of game for London is going steadily up,' it ran. 'Head-keeper Hudson, we believe, has been now told to receive all orders for fly-paper and for preservation of your henpheasant's life" (Doyle, 2019, p. 301).

- deception, or deceit, leading the addressee into error (made-up stories about non-existent Bunbury in O.Wilde's play "The Importance of Being Earnest") (Wilde, 2002) and so on.

At the third (interactive) level communication noise is caused by:

- difference between communicative purposes and strategies of the communicants, communicative pressure, the wish to lower "the face status" of the interlocutor:

"Can I have a word with you, Wooster?"

"Of course, of course. Have several."

He did not speak for a minute or so, filling in the time by subjecting me to a close scrutiny. Then he gave a sigh and shook his head.

'I can't understand it,' he said.

"What can't you understand, Spode old man or rather Lord Sidcup old man?" I asked in a kind voice, for I was only too willing to help this new and improved Spode solve any little problem that was puzzling him.

"How Madeline can contemplate marrying a man like you. She has broken our engagement and says that's what she's going to do. She was quite definite about it. "All is over», she said. «Here is your ring», she said. «I shall marry Bertie Wooster and make him happy», she said. You can't want it plainer than that" (Wodehouse, 2004, p. 77).

- the communicant's lack of interest in the communicative act, being absorbed in his/her problems:

"Don't go to the police."

"We won't go to the police," said Agatha. "And there's no evidence. All the evidence was burnt in the fire."

Mavis's eyes narrowed. "So where the hell do you pair get off, tormenting me?" She stood up. "Get out of here!' (Beaton, 1999, p. 94).

- the speaker's unwillingness to continue communication with the addressee, caused by an insult or a violation of the speech etiquette, a particular emotional state of the communicants, intimacy of the topic that has been touched upon, etc.:

"And what about you, Agatha?" asked Olivia. "Rose told us she remembered reading about you. Your husband was murdered just as you were about to marry James here. It's a wonder he's forgiven you."

"He hasn't and won't, ever," said 
Agatha, her eyes suddenly filling with

tears. "Excuse me." She rose to her

feet and went to the toilet and leaned against the wash-hand basin" (Beaton, 1997, p. 40).

- the speaker's wish to avoid an undesirable topic:

"I've been looking for you,' shouted

Adam. 'I want some money."

'Can't hear--what do you want?'

'Money.'

'It's no good--these infernal things

make too much noise. What's your

name? Lottie had forgotten.'

'Adam Symes.'

"Can't hear" (Waugh, 2012, p. 113).

- the use of implicit speech acts, hints, with the addressee's inability to identify the speaker's illocution:

"I am going everywhere that Wilbert

Cream goes, and one speculates with some interest as to what the upshot will be. He resents my constant presence.'

'Has he said so?'

'Not yet. But he gives me nasty looks.'

'That's all right. He can't intimidate me.'

I saw that she was missing the gist.

'Yes, but don't you see the peril that looms?'

'I thought you said it lurked.'

'And looms. What I'm driving at is that

if I persist in this porous plastering, a time must inevitably come when, feeling that actions speak louder than words, he will haul off and bop me one" (Wodehouse, 2009, p. 29).

At the fourth (ontological) level communication noise is caused by the intervention of other people creating a new discourse and putting an end to the conversation with the previous interlocutor; irrelevant for the topic of the communication deviations impeding the perception of communicants' speech; as well as irrelevance of circumstances and conditions of communication.

At the fifth (sociocultural) level communication noise is caused by ignoring social standards, communicative conventions, and speech etiquette (e.g., ignoring parents' or children's status, which is culturally determined, rudeness, insults), non-differentiation of institutional / noninstitutional, or formal/informal communication, ignoring cultural stereotypes, norms, conventions, and values of a culture or subculture (e.g., communication with slang, jargon, or argot bearers), ignorance of precedential phenomena, culturally marked symbolic and paraverbal signals (e.g., the use of unacceptable for certain culture gestures, violating the distance between the communicants in intercultural communication, etc.).

Communication noise and its origin in intercultural communication were first investigated by R. Yakobson (1975) in his article "Linguistics and the theory of interrelation". Communication noise is said to be caused by lacune character of the interrelation between a particular linguocultural community with another one (Sorokin \& Markovina, 1983; "Ethnic-psycholinguistics", 1988 , p. 234). The intermediary of interlingual communication is translation as interpretationbased discourse, causing the collision of NOT ONLY two verbal codes, but also the codes of paraverbal level, as well as of culture and ontology (Selivanova, 2000, pp. 51-55).

The translator's inaptitude to compensate for the difference of the codes causes communication failure and communicative conflict. In order to avoid communication noise researchers recommend to use H.P. Grice's maxims. For instance, M. Clyne (1994) has come up with his own correction of H.P. Grice's maxims under the norms of intercultural communication. The Gri- 
cean maxim of Quantity: "Make yourself as informative as is required. Do not make your contribution more informative than is required"5 (Grice, 1991) reads as follows in Clyne's (1994) revision: "Make your contribution as informative for the purpose of the discourse, within the bounds of the discourse parameters of the given culture parameters (e.g. form/content, oral/literate, rhythm, directionality, concreteness/abstractness)". The maxim of Quality: "Do not say what you believe to be false. Do not say that for which you lack adequate evidence" sounds in Clyne's revision: "Do not say what you believe to be in opposition to your cultural norms of truth, harmony, charity and/or respect". The Maxim of Manner "Avoid obscurity of expression" sounds in Clyne's revision: "Do not make it any more difficult to understand than maybe dedicated by the question of face and authority" The submaxim "Avoid ambiguity" is reformulated to: "Make clear your communicative intent unless this is against the interests of politeness or of maintaining a dignity-driven cultural core value, such as harmony, charity or respect". The submaxim "Be brief " is revised to: "Make your contribution the appropriate length required by the nature and purpose of the exchange and the discourse parameters of your culture". The submaxim "Be orderly" is revised to: "Structure your discourse according to the requirements of your culture" (Clyne, 1994).

At the cognitive-interpretational level communication noise in intercultural interaction is caused by the discrepancy of the principles of reality categorization and that of inner reflexive experience in the ethnical conscience of two peoples (e.g., the perception of time in mono-

\footnotetext{
See: Grice's Conversational Maxims applied to Chatbot... https://medium.com/swlh/grices-conversational-maxims-applied-to-chatbot-conversational-uxdesign-e8c4ba670c41.
}

chronic and polychromic cultures, categorization of possessiveness in European languages and Melanesia; the classifiers of an Australian aboriginal tribe, analyzed by G. Lakoff (1987).

Through translation, experience specification reflected in a language encounters generalization in another language. Noise effects are also determined by the differences in the conceptualization of things and phenomena reflected in the verbal code (e.g., about 5000 names of camel, parts or its body and equipment in the Arabic language, more than a hundred names of snow in the languages of northern peoples).

At the sociocultural level of intercultural communication, noise is caused by the speaker's lack of knowledge norms, regulations, and values of a foreign culture, its myths, stereotypes, symbols, precedential phenomena, etc. Communication noise is eliminated by the translator employing commentary and footnotes. To illustrate, in one of F. G. Lorca's lectures communication noise is removed in the following fragment: "Let us also walk blindfold, leaving our eyes on the icy platter, so that St. Lucia wouldn't plume herself anymore". The communication noise is eliminated by a commentary: "According to a legend, St. Lucia struck herself blind not to attract admirers; she is usually depicted with a tray holding her eyes". Sometimes a misunderstanding of foreign realia is removed by their substitution (Ukrainians call the Granada melody villancico a Christmas carol; for Mexican Indians who have never seen the sea, a fragment from the Bible about a trip overseas is translated as a trip beyond the swamp).

Mismatching of cultural-ontological spheres can utterly rebuild verbal coding in intercultural communication. Here is an example of such recoding reported by K. Kluckhohn (1949): when a Japanese was asked to translate a phrase from 
The Constitution of The United States "Life, Liberty and the pursuit of Happiness", he translated it as "permission to indulge in lust".

The investigation of communicative noise at various levels of monocultural and intercultural communication, as well as the ways to avoid it results in working out recommendations for effective and optimal communicative interaction, harmonious relationship of communicants, their mutual understanding and cooperation. The raised issues offer prospects for further research, such as investigating of noise effects in real communication, identifying a set of causes leading to communication noise, as well as noise-resistant factors, preventing or removing it.

\section{REFERENCES}

Beaton, M. C. (1987). Death of a Cad. London: St. Martin's Press.

Beaton, M. C. (1997). Agatha Raisin and the Terrible Tourist. London: St. Martin's Press.

Beaton, M. C. (1999). Agatha Raisin and the Wizard of Evesham. London: St. Martin's Press.

Beaton, M. C. (2001). Death of a Dustman. London: Mysterious Press.

Beaton, M. C. (2009). Agatha Raisin and the Day the Floods Came. London: C \& R Crime.

Beaton, M. C. (2011). Death of a Perfect Wife. London: C \& R Crime.

Bigunova, N. (2019, June). Cognitive Pragmatic Regularities in Communicative Manifestation of Positive Evaluation. Lege Artis. Language Yesterday, Today, Tomorrow. The journal of University of SS Cyril and Methodius in Trnava. Trnava: University of SS Cyril and
Methodius in Trnava, $I V(1), 2-46$.

Clyne, M. (1994). Intercultural Communication at Work: Cultural Values in Discourse. Cambridge: CUP.

Doyle, A. C. (2019). The Complete Sherlock Holmes. London: Chartwell Books.

Eco, U. (1989). The Open Work. Massachusetts: Harvard University Press.

Eco, U. (1998). Otsutstvuyushchaya struktura. Vvedenie v semiologiyu (Absent Structure, Introduction to Semiology, in Russian). Moscow: Petropolis.

Etnopsiholingvistika (Ethnic-Psycholinguistics, in Russian). (1988). Moscow: Nauka.

Fillmore, C. (1982). Frame Semantics. Linguistics in the Morning Calm, 111-137.

Frumkina, R. M. (1995). Pragmatika: novyii vzglyad (Pragmatics: A New Overlook, in Russian). Semiotics and Informatics, 34, 98-113.

Frumkina, R. M. (2003). Psikholingvistika (Psycholinguistics, in Russian). Moscow: Akademiya.

Goldiamond, I., \& Hawkins, W. F. (1958). Vexierversuch: The Log Relationship between Word-Frequency and Recognition Obtained in the Absence of Stimulus Words. Journal of Experimental Psychology, 56(6), 457-463.

Grice, H. P. (1991). Logic and Conversation. In H. P. Grice (Ed.), Studies in the Way of Words (pp. 22-40). New York: Academic Press.

Haddon, M. (2012). The Curious Incident of the Dog in the Night-time. London: Vintage Digital.

Hobbes, T. (1994). Leviathan. Indianapolis \& Cambridge: Hackett Publishing Company.

Kinsella, S. (2003). Can You Keep a Secret? 
London: Black Swan.

Kluckhohn, C. (1949). Mirror for Man. New York: Fawcett.

Lakoff, G. (1987). Women, Fire and Dangerous Things. Chicago: The University of Chicago Press.

Leech, G. (1981). Semantics. London: Penguin Books.

Leibniz, G. (1989). Philosophical Essays (R. Ariew \& D. Garber, Eds. \& Trans.) Indianapolis \& Cambridge: Hackett Publishing Company.

Leontev, A. A. (1999). Osnovy psikholingvistiki (The Basis for Psycholinguistics, in Russian). Moscow: Smysl.

Makarov, M. L. (2003). Osnovyi teorii diskursa (The Basis for Discourse Studies, in Russian). Moscow: Gnozis.

Martin, R. C., \& Freedman, M. L. (2001). Short-Term Retention of Lexical-Semantic Representations: Implications for Speech Production. Memory, 9(4/5/6), 261-280.

Oliinyk, G. O. (2019). Verbalni ta neverbalni zasoby vyrazhennia nerozuminnia $v$ suchasnomu anhlomovnomu literaturnomu ta kinodyskursi: kohnityvnoprahmatychne doslidzhennia (Verbal and Nonverbal Communicative Means of Expressing Misunderstanding in Modern English Literary and Film Discourse: Pragmatic Cognitive Research, in Ukrainian). ( $\mathrm{PhD}$ thesis). Odessa: Odesa I.I. Mechnikov National University.

Rechevyie priemyi i oshibki: Tipologiya, derivatsiya, funktsionirovanie (1989). (Speech Methods and Mistakes: Typology, Derivation, Functioning, in Russian). Moscow: Prosveshchenie.
Rothwell, D. J. (2004). In the Company of Others: An Introduction to Communication. New York: McGraw Hill.

Selivanova, O. O. (2010). Linhvistychna entsyklopediia (Linguistic Encyclopedia, in Ukrainian). Poltava: Dovkillia-K.

Selivanova, Y. A. (2000). Lingvokulturnyi aspekt kommunikativnogo shuma (Linguocultural Aspect of Communication Noise, in Russian). International Scientific Conference LINGVAPAX 8. Kiev: UNESCO, KSLU, 3, 51-56.

Shannon, C. E., \& Weaver, W. (1949). The Mathematical Theory of Communication. Urbana, IL: University of Illinois Press.

Shklovsky, V. (1990). Theory of Prose. (B. Sher, Trans). McLean, IL : Archive Press.

Smith, Z. (2001). White Teeth. London: Penguin. Sorokin, Yu. A., \& Markovina, I. Yu. (1983). Opyt sistematizatsii lingvisticheski $i$ kul'turologicheski lakun (Experience of Systematization of Linguistic and Culturological Lacunes, in Russian). In Lexical Units and Organization of Text Structure (pp. 215-257). Kalinin: Kalinin State University.

Susov, I. P. (1988). Deyatelnost, soznanie, diskurs $i$ yazykovaya skhema (Activity, Conscience, Discourse, and Language Scheme, in Russian). In Speech Communication: Processes and Units (pp. 7-13). Kalinin: Kalinin State University.

Tarasova, E. V. (2000). Rechevaya sistemnost' v terminakh (Speech Systematization in Terms, in Russian). The Journal of $V$. N. Karazin Kharkiv National University, 471, 276-283.

Trollope, J. (2010). The Other Family. New 
York: Transworld Digital.

Twain, M. (2012). The Adventures of Tom Sawyer. London: Vintage Digital.

Uhtomskiy, A. A. (1950). Sobranie sochineniy (Complete Works, in Russian). Leningrad: Leningrad state university.

Waugh, E. (2012). Vile Bodies. New York: Hachette.

Wilde, O. (2002). The Importance of Being Earnest. London: Penguin Books.
Wodehouse, P. G. (2004). Much Obliged, Jeeves. New York: Everyman.

Wodehouse, P. G. (2009). Jeeves in the Offing. New York: Cornerstone Digital.

Wodehouse, P. G. (2015). Right Ho, Jeeves. London: Otbebook publishing.

Yakobson, R. (1975). Lingvistika i poetika (Linguistics and Poetics, in Russian). Structuralism: "for" and "against": a collection of articles, 193-230. 